\title{
Theory of Science Perspectives on Strategic Management Research \\ Debates and a Novel View
}

Foss, Nicolai Juul

Document Version

Final published version

Publication date:

2007

License

CC BY-NC-ND

Citation for published version (APA):

Foss, N. J. (2007). Theory of Science Perspectives on Strategic Management Research: Debates and a Novel View. Center for Strategic Management and Globalization. SMG Working Paper No. 7/2007

Link to publication in CBS Research Portal

\footnotetext{
General rights

Copyright and moral rights for the publications made accessible in the public portal are retained by the authors and/or other copyright owners and it is a condition of accessing publications that users recognise and abide by the legal requirements associated with these rights.

Take down policy

If you believe that this document breaches copyright please contact us (research.lib@cbs.dk) providing details, and we will remove access to the work immediately and investigate your claim.
}

Download date: 26. Apr. 2023 


\title{
Theory of Science Perspectives on Strategic Management Research: Debates and a Novel View
}

\author{
Nicolai J. Foss
}

SMG WP 7/2007

June 2007 
SMG Working Paper No. 7/2007

June 2007

ISBN: 978-87-91815-06-5

Center for Strategic Management and Globalization Copenhagen Business School

Porcelænshaven 24

2000 Frederiksberg

Denmark

www.cbs.dk/smg 


\title{
THEORY OF SCIENCE PERSPECTIVES ON STRATEGIC MANAGEMENT RESEARCH: DEBATES AND A NOVEL VIEW
}

\author{
Nicolai J. Foss \\ Center for Strategic Management and Globalization \\ Copenhagen Business School \\ Porcelænshaven 24, $2^{\text {nd }}$ fl.; 2000 Frederiksberg; Denmark \\ njf.smg@cbs.dk \\ and \\ Department of Strategy and Management \\ Norwegian School of Economics and Business Administration \\ Breiviksveien 40; N-5045; Bergen; Norway \\ Prepared for \\ The Elgar Handbook of Research on Competitive Strategy \\ Edited by Giovanni Battista Dagnino
}

May 30, 2007; word count (main body): 7,926

KEYWORDS: The theory of science, strategic management, reduction

JEL CODE: $\quad$ B40, M1

\section{ACKNOWLEDGMENTS}

Parts of this paper draws on Nicolai J. Foss, "Scientific Progress in Strategic Management: The Case of the Resource-based View," Center for Strategic Management and Globalization, Copenhagen Business School, WP-2005-11. 
THEORY OF SCIENCE PERSPECTIVES ON STRATEGIC MANAGEMENT

RESEARCH: DEBATES AND A NOVEL VIEW

\begin{abstract}
Arguments derived from the theory of science have been present in strategic management discourse since at least the beginning of the 1970s. The field's topjournal, the Strategic Management Journal, has printed several theory of sciencebased papers. Most positions in the theory of science (falsificationism, instrumentalism, realism, constructivism, etc.) have been present in the methodological discourse in the field. This chapter briefly reviews theory science applications to strategic management, before a distinctive perspective on the evolution of the strategic management field is developed. According to this perspective, science progresses when deeper level mechanisms are identified and theorized. Theoretical reduction may therefore be an independent criterion of scientific progress. Application to the strategic management field of this perspective, which in the social sciences is closely connected to the notion of methodological individualism, reveals that the field has evolved in a manner akin to a swinging pendulum, oscillating between micro and macro perspectives.
\end{abstract}




\section{INTRODUCTION}

Strategic management researchers are, as a rule, practically oriented folks who typically do not have much patience with lofty debates in the theory of science. Say the word "ontology" and you will have eyes rolling in the audience (yes, I have tried it!). Still, treating strategic management in a theory of science perspective actually goes back at least to Bowman (1974), and quite a number of papers on essentially philosophical issues in strategic management have been published in strategic management top journals, notably the Strategic Management Journal over the last two decades. Quite often - in fact, usually — these contributions mirror and apply established arguments in the theory of science literature, for example, work on the growth of knowledge (e.g., Camerer, 1985; Balakrishnan et al., 1989), constructivism versus realism (e.g., Smircich and Stubbard, 1985), the role of unobservables (Godfrey and Hill, 1995), the rhetorical practice of strategic management scholars (Mahoney, 1993), so-called “critical theory” (e.g., Knights and Morgan, 1991; Alvesson and Willmott, 1995), and even “deconstruction” (Whipp, 1996).

Moreover, strategic management scholars are what be called "implicit theorists of science.” For example, they are intensely occupied with theoretical change in their field and with the reasons for such change (e.g., Hoskisson et al., 1999), essentially methodological undertakings. In fact, the purpose of the highly influential bi-annual special issues of the Strategic Management Journal is not only to take stock on existing developments, but more importantly to signal major changes in the field. Scholars actively debate those changes, and often to do in what is essentially a philosophy of science mode. For example, they may debate whether the adoption by the strategic management community of certain core ideas (e.g., the RBV approach to competitive advantage) leads to a "loss of content" (Kuhn, 1970) (i.e., other ideas are forgotten - such as notions of positioning?). They may debate the relations between old and new strategy theories (e.g., rival or complementary; Mahoney and Pandian, 1992; Oliver, 1997; Foss, 1999). Or, they may issue the charge of tautology, a widespread practice in debate on the RBV (Porter, 1991; Black and Boal, 1994; Priem and Butler, 2001; Powell, 2001).

Clearly, all such discussions fundamentally touch on theory of science issues, as a traditional key concern of the theory of science has been the criteria that practising 
scientists apply for the evaluation of theories and choice among rival theories. In this chapter I shall make reference to, and briefly review and discuss a subset of these discussions. However, the aim of the chapter goes further than reviewing existing contributions.

Thus, I also discuss and draw attention to some more neglected (in the strategic management field) theory of science aspects of strategic management, notably mechanism-oriented explanation and the need for micro-foundations. These belong to the theory of science proper, because they touch on issues of how we grapple with social ontology through the modes of explanation we apply (see also Tsoukas and Knudsen, 2002). Moreover, I shall argue that issues that relate to mechanisms and levels of analysis are among the reasons that scientists give and legitimately can give for rejecting or accepting theories. In fact, one can hold the view that scientific progress is the theoretical and empirical uncovering of the workings of the causal mechanisms that produce observable events (cf. Elster, 1989). One can go even further, and hold that such uncovering and theorizing of generative mechanisms usually entails reduction, that is, moving down the ladder of levels of analysis. In this view, which I shall state and defend, reduction is not simply a matter of explanation, but a distinct criterion for scientific progress. Whether strategic management has made scientific progress on this criterion is debatable. Specifically, I develop a variant of the "swinging pendulum" thesis of Hoskisson et al. (1999), and argue that strategic management research has oscillated between giving explanatory primacy to collective entities, or to micro-entities and their interaction. The latter is, I argue, preferable.

\section{THE THEORY OF SCIENCE AND STRATEGIC MANAGEMENT}

\section{The Theory of Science}

As a branch of epistemology, the theory of science has historically had a number of aims, although the priorities have changed quite dramatically, perhaps particularly over the last twenty years. A traditional aim has been to characterize science as a distinct field of inquiry, to describe the procedures that secure (if indeed they do) scientists privileged access to Nature's Secrets, and to identify the criteria - such as potential falsifiability (Popper, 1934) — that may distinguish scientific from non-scientific arguments (i.e., the “demarcation problem”). A closely related activity has been the search for criteria of 
scientific progress. Other traditional (that is, at least within the last hundred years) theory of science concerns have centered on the objectivity vs. theory-laden'ness of observations; the indeterminacy of theory under empirical testing (the Duhem-Quine thesis); induction versus falsification; the clash between scientific realism and instrumentalism; foundationalism vs scepticism; and, more recently, constructivism, issues of scientific open'ness, and the sociology and anthropology of science.

As indicated in the Introduction, virtually all of these themes can be found whether implicitly or explicitly — in the theory of science literature in strategic management. Overall, however, the theory of science themes that have made the most frequent appearances in the strategic management journals are those associated with the so-called "growth of knowledge" literature (Popper, 1934; Kuhn, 1970; Lakatos, 1970; Feyerabend 1974; Laudan, 1977). These have also been the most important inputs into theory of science-discussion in economics, perhaps the most important foundational discipline of the strategic management field. A brief review may therefore be in order.

\section{The Growth of Knowledge Literature}

The growth of knowledge literature is conventionally taken to begin with Popper (1934) and continue in his development of what he came to refer to as "critical rationalism,” an approach that fundamentally involved the idea that all knowledge is inherently conjectural (fallibilism) and cannot be verified by testing, only falsified. The growth of (scientific) knowledge entered the picture in Popper's thinking from his wrestling with the problem of aligning fallibilism with the observed growth of knowledge. Popper's solution to the problem was evolutionary epistemology, that is, the idea that the growth of knowledge may be explained making use of such fundamental evolutionary mechanisms as the variation-heredity-selection triad, corresponding to competiting conjectures, background knowledge (problem situations arise against background knowledge; conjectures that have withstood falsification attempts become part of background knowledge), and falsification leading to error elimination, respectively. Popper seems to have thought of this as a descriptive model of the growth of knowledge, although he was aware that his emphasis on bold conjectures (the variation mechanism in his evolutionary epistemology) was more normative than strictly descriptive. 
In terms of the mechanisms underlying Popper's evolutionary epistemology, Kuhn and Lakatos can be understood as de-emphasizing the variation and selection part in favor of strongly emphasizing the heredity part. Thus, both argued that individual theories are embedded in larger cognitive structures, the famous "paradigms" (Kuhn, 1970), that supplied large parts of the theoretical components of those individual theories. In fact, Kuhn rejected the idea that scientists pursue bold conjectures and attempt to falsify their theories. Lakatos is often portrayed as a sort of halfway house between Popper and Kuhn: While he adopted the paradigm idea, substantially refining it, he clearly admitted that falsification played a role.

The important organizing category in Lakatos' model is "the scientific research program”, which is clearly a more elaborate version of Kuhn's concept of paradigm (and minus ideas on incommensurability). Specifically, it should be thought of as a series of theories that comprise a continuous whole because they share some so-called "hard core propositions" and are constructed according to heuristics that are specific to the scientific research program. The research program changes by modifying propositions in the "protective belt" (the "positive heuristic" informs the researcher about how this should legitimately be done, and the negative heuristic informs him about what cannot legitimately be done), while keeping intact the hard core. As such, this is a descriptive model of scientific activity. However, Lakatos adds a normative dimension by introducing notions of progression and degeneration. In his scheme, scientific progress obtains if a new theory within a research program has "excess empirical content” in the sense that it puts forward some "novel fact", some hitherto unnoticed prediction, which apparently (Lakatos is far from forthcoming here) should be understood as predicting novel phenomenon. Degenerating research programs are those that fail to develop novel facts and/or where theories belonging to the programme repeatedly are falsified.

\section{The Theory of Science in Economics}

In the social sciences, the growth of knowledge literature became particularly influential in economics, arguably the discipline that overall has influenced strategic management the most. Specifically, a watered down version of Popperian falsificationism in the guise of Friedman's (1953) brand of instrumentalism became hugely influential in economics. The growth of knowledge literature became relatively influential in economics 
in the 1970s and 1980s. In particular, Lakatos' methodology of scientific research programme proved influential.

Thus, a cottage industry — now very much a sunset industry — that explored various changes in economic theory in analytical terms from the growth of knowledge literature developed in the 1980s (see Backhouse [1994] for a post mortem). Economic methodologists gradually realized that economists were not terribly scrupulous with respect to practising the falsificationism they hailed in their rhetorical practice. Whereas Blaug (1980) saw this as a problem for economists, increasingly it came to be seen as a problem for Popperian falsificationism. Similarly, it was found that it was quite hard to come up with convincing examples of Kuhnian revolutions or Lakatosian novel facts in economics (DeMarchi and Blaug, 1991; Backhouse, 1994; Foss, 1998).

As a consequence, the focus began to shift to examining the actual practice of economists, that is, to those criteria that may be inferred through the actual choices that are being made in theory-building, and away from abstract and context-independent criteria for theory choice (e.g., Mäki, 1992). The wish to pass judgment on actual theory choice was also downplayed. Partly in parallel with this, the economics profession had a brief flirtation with rhetorical analysis, that is, the actual acts of persuasion that practising economists employ to convince their peers of the soundness of their arguments (McCloskey, 1983). And some of the reorientation away from the growth of knowledge literature took place in tandem with and to some extent inspired by currents in the sociology of science, notably the various (“strong”, "weak") "programs” in the sociology of science (e.g., Bloor, 1976). ${ }^{1}$

\section{Theory of Science Debates in Strategic Management: Overall}

Strategic management is in a number of ways reminiscent of economics, not only because economics is an important foundational input in strategic management research, or because many strategic management scholars have an economics background, but also because strategic management seems to have gone through rather similar waves of methodological discussion and opinion. Thus, some of the first theory of science-based statements in strategic management were informed by arguments from the growth of

\footnotetext{
${ }^{1}$ However, unlike the situation in many other social sciences, very few economists and economic methodologists have bought into the more extreme positions associated with the strong program in the sociology of science.
} 
knowledge literature. Such statements were forcefully put forward by Camerer (1985) and Balakrishnan, Montgomery and Wernerfelt (1989), that is, strategy scholars strongly influenced by economics. In particular, these scholars criticized the lack of falsifiable analytical content in strategy content research. Growth of knowledge arguments continue to be invoked in methodological discourse in strategic management (e.g., Bogner et al., 1998; Powell, 2001: 876).

However, as is the case in the theory of science in general as well as in economics, initial enthusiasm with growth of knowledge philosophers has given way to more "pluralistic" positions (e.g., Bowman 1990). For example, the "rhetorical” approach of economic historian Donald (now Deirdre) MacCloskey (1983) was forcefully applied by Mahoney in a string of papers in the beginning of the 1990s (e.g., Mahoney and Pandian, 1992; Mahoney, 1993).

It is not difficult to see why strategic management scholars initially interested in growth of knowledge arguments may gradually have become somewhat uncomfortable with them. On the one hand, strategic management is a very strongly empirical field. Almost from the takeoff of strategic management as a scientific field (circa 1980 - i.e., the launch of the Strategic Management Journal and the publication of Porter, 1980)), the majority of researchers in their scientific practice conformed to the covering law approach to explanation and prediction (Hempel, 1965) and expressed a clear preference for the variable-centered (large- $N$ ) “variance approach" of empirical research practice rather than other (rigorous) approaches (e.g., Abell, 2001, 2004). Hypothesis formulation and testing in the context of large- $N$ samples was, and is, the order of the day, and the vast majority of papers published in the leading journals that publish strategic management research take this approach. On the other hand, it also seems clear that most strategic management researchers do not follow falsificationism in the form espoused by Popper, but rather the “... statistical view of testing that accepts that neither refutation nor confirmation can ever be final, and that all we can hope to do is to discover on the basis of finite amounts of imperfect knowledge what is the balance of probabilities among existing hypotheses” (Lipsey, 1966: 184). Thus, strategic management research practice may not confirm to at least strict falsificationism. 
Moreover, the Kuhnian and Lakatosian schema seem difficult to apply to a field that does not go back more than at most fifty years as even a practical field, and perhaps only about thirty years (or less) as a scientific field. It is not clear that there are in any meaningful sense Kuhnian paradigms or Lakatosian scientific research programmes in strategic management. In addition, it is unclear what are the Lakatosian "novel facts" in strategic management research (perhaps depending on how exactly that enigmatic concept is defined). To be sure, “competitive advantage," whether sustained or not, hardly qualifies as a novel fact, as the recognition that some firms are more successful than others on a sustained basis certainly characterizes any strategy content approach, and indeed may be seen as the defining overall research question of the field.

\section{Recent Methodological Debate in Strategic Management}

What is here interpreted as a rejection of traditional growth of knowledge arguments by no means imply that strategic management scholars have given up on discourse that applies theory of science arguments. Strategic management scholars continue to vigorously debate methodological issues and the subject seems to have increased in popularity recently, as witnessed by the spate of methodological work that has appeared in the pages of the Strategic Management Journal over the last decade.

Relative to earlier methodological pronouncements which tended to be relatively abstract and aloof, and mainly related to existing research practice in a highly critical manner (the high point of this is surely Camerer, 1985), recent methodological work tends to more explicitly relate to existing problems in strategic management research. For example, the advent and eventual dominance of the resource-based view raised a traditional problem in the theory of science - what is the explanatory role of unobservables? - , as that view often emphasizes knowledge resources, and particularly tacit ones. Godfrey and Hill (1995) applied traditional philosophy positions (positivism and realism) to the debate, ultimately siding with the realist view that unobservables may be defended in terms of "inference to the best explanation" (i.e., abduction), in other words, a better performing (predicting) theory that involves unobservables is preferred on account of its superior performance (Lipton, 2004).

Also reflecting the increased dominance of the resource-based view, Powell (2001) explored philosophical aspects of the link between sustained competitive advantage and 
sustained financial performance that is foundational to the strategic management field. He provocatively argued that 1) sustained competitive advantage is neither sufficient nor necessary to sustained financial superiority; 2) there is no contemporary falsifiable, unfalsified theory of sustained competitive advantage; and 3) discussion of competitive advantage is really a Wittgensteinian language game which, however, may be defended on pragmatist grounds for its usefulness to the strategic management field. Powell's paper gave rise to two responses. Durand (2002: 868) took particular issue with Powell's point 1) and constructed an argument that “... competitive advantage is a sufficient but notnecessary condition requiring a conjunctive factor, which is presumably organization.” Arend (2003: 281) admitted Powell's point 2), but argued that even tautological and analytical propositions may be useful, because they supply "measures and laundry lists of possible manifestations of the elements of such propositions such as bargaining power, contracting costs, inimitability, and the like" that provide decision-makers with helpful categories with which to classify and arrange real phenomena. ${ }^{2}$

On the whole, it is characteristic of recent theory of science-based discourse in strategic management that scholars, in contrast to earlier ambitious statements by Camerer (1985) and Balakrishnan et al. (1988), seem to have given up on putting forward strong recommendations for research practice, such as generally condemning research practice for its failure to cast reasoning in sufficiently analytical terms or to honor Popperian ideals of falsification. Instead, they are taken up with such issues as the logical structure of specific arguments in strategic management (e.g., Brønn, 1998; Powell, 2001) or whether the evolution of the field can be characterized as a move towards embracing more “organic” conceptions (Farjoun, 2002).

There is a stronger descriptive than normative stance in recent contributions, and often a strong attempt to relate to actual research practice. To illustrate how far this can go, in a discussion of whether Kuhn's paradigm development model applies to strategic management, Boyd et al. (2005) actually develop concrete measures that may allow for an

\footnotetext{
${ }^{2}$ Another millennium debate was sparked by Mir and Watson (2000) arguing in favour of a constructivist approach (partially against the realism of Godfrey and Hill, 1995) to understanding the evolution of the strategic management field. Among other things, they took issue with the dominance of cross-sectional research methods in the field. Kwan and Tsang (2001) argued that Mir and Watson had misconstrued realism. A reply by Mir and Watson (2001) upheld the constructivism/realism distinction. In contrast to the debate initiated by Powell (2001) the debate initiated by Mir and Watson touched more on philosophy than on strategic management.
} 
assessment of the maturity of the strategic management field. ${ }^{3}$ This increased orientation to the actual research practice of the field may reflect the corresponding development of the theory of the science over the last decades. However, it may also reflects that strategic management is now more established in terms of research heuristics, and agreement on what are the key problems, the key variables and the key findings than it was in the 1980s (but see Mintzberg et al., 1998); accordingly, there may simply be less to criticize from a theory of science perspective.

Still, there may be things left for the methodologist to normatively relate to. I propose in the following that one important way (certainly not the only one) in which strategic management progresses as a scientific field is by means of performing analytical reduction, that is, showing how phenomena on a given level of analysis is really constituted by the action and interaction of entities, ultimately human beings, at levels lower down. On this basis, it is possible, I argue, to pass (cautious) methodological judgment on the evolution of the field.

\section{A DIFFERENT VIEW: REDUCTION AS PROGRESS}

\section{Of Reduction and Reductionism}

The notions of reduction and reductionism are highly context-dependent. Historically, these notions have been associated with more or less controversial positions such as mechanism, physicalism, and methodological individualism (Dupree, 1993; Jones, 2000). While the notions of reduction and reductionism, as they are used here, are closely related to methodological individualism, they have nothing to do with mechanism or physicalism. The aim is not to pursue the kind of charicature reductionism well known from debates in natural science:

An extreme and classical kind of reductionism holds that all laws governing the behaviour of complex objects should be deducible from the laws of lower-level science and thus, ultimately, the laws of all sciences should be deducible from those of particle physics” (Dupré, 2001: 309).

\footnotetext{
${ }^{3}$ Specifically, they “.... conduct two studies. The first is a cross-discipline comparison of productivity norms for university faculty. The second study examines longitudinal research outcomes for a sample of 945 strategy faculty. Our results indicate that strategy has the attributes of both an early stage and mature field: while overall research norms are low relative to other fields, they are driven far more by merit-based than non-merit factors" (2005: 841).
} 
Applied to strategic management such a view would imply that competitive advantage be reduced to the genetic endowment of firm founders (and, indeed, ultimately to the laws of particle physics); most likely a pointless exercise.

By "reduction," then, is here understood the process of explaining a particular phenomenon in terms of more fundamental phenomena. By "reductionism" is here understood the explanatory position that the best understanding of a complex, and in social science: collective-level, phenomenon “... should be sought at the level of structure, behaviour and laws of its component parts plus their relations” (Silberstein, 2002: 81). It entails a search for the "deep structure” underneath aggregate phenomena (Williamson 1996). While "reduction" is a description of an analytical operation, reductionism is a normative stance; it asserts that reduction is something worth striving for, and that science progresses when reductions are performed.

\section{Reductionism and Scientific Progress}

The argument here is that reduction is more than an analytical operation; it may constitute a criterion of scientific progress. On this criterion, a body of knowledge (whether a theory, research program, paradigm, research tradition, etc.) makes progress when a novel analytical reduction is performed. Such a "novel analytical reduction" takes place when one or more explanatory mechanisms, constructs, etc. that were hitherto treated in a blackbox manner are opened up and addressed in terms that are congenial to the other elements of the body of knowledge.

Reductionism is a close allied of philosophical realism because it entails a sustained attempt to identify and theorize the real causal mechanisms - the "cogs and wheels" (Elster, 1989: 3) — that generate and explain observed associations between observed events (Harré, 1970; Bhaskar, 1978). ${ }^{4}$ It is, however, different from the covering-law model of explanation of Hempel and others, because the covering-law model does not imply an insistence on identifying causality.

Now, whereas reductionism is naturally associated with philosophical realism, the reverse is not necessarily true: One can be a realist and hold that understanding "real causal mechanisms" requires doing the opposite of reduction. Some structuralist

\footnotetext{
${ }^{4}$ On the role of mechanisms in explanation, see the essays in Hedström and Swedberg (1998).
} 
sociologists may instantiate this position. In contrast, the reductionist position holds that the real causal mechanisms are usually located at the same or lower levels of analysis than the explanandum phenomenon, and that identifying and theorizing such mechanisms means scientific progress. ${ }^{5}$ There is a pragmatic dimension to this, because a better understanding of real generative mechanisms usually translates into better control (cf. Coleman, 1990: Chapter 1).

Reductionism in this sense is not an extraneous criterion for scientific progress; it seems to be something that many practising social scientists subscribe to. This is particularly the case of economists (cf. also Mäki, 2001) and sociologists and political scientists who work from a rational choice basis. Thus, a massive research effort in economics over the last three decades has sought to understand aggregate phenomena, whether macro-economic outcomes or institutions, as the (possibily unintended) result of the interaction of rational individuals. The new institutional economics, contract theory, political economy, and a number of approaches in macro-economics (new classical as well as new Keynesian) are instances of this overall effort, exemplifying how strong the drive towards reduction is in economics. While reduction is by no means the only criterion that economists apply to theory evaluation, it is surely an important one and one shared by most economists. And while strategic management scholars are by no means similarly uniform with respect to reduction and reductionism, a number of strategic management scholars may, as I argue later, be seen as reductionists (e.g., Barney, 2001; Coff, 1999.; Lippman and Rumelt, 2003). ${ }^{6}$

\section{What Reductionism Is Not}

Reductionism has generated much heated controversy (Dupree, 1993; Jones, 2000), including controversy in strategic management. For example, Bourgeois (1984: 586) argued that “... reductionism eliminates much of the richness that characterizes the strategic management process” (the basis for this assertion remains, however, unclear). As the position here is the exact opposite — we need more reductionism in strategic

\footnotetext{
${ }^{5}$ Although Elster's (1989: 74) dictum that “[r]eduction is at the heart of progress in science,” would likely be accepted by many scientists and philosophers, I am not aware of any sustained theory of science discussions of reduction(ism) as (a) progress (strategy).

${ }^{6}$ It is very likely that disciplinary background plays an important role here, strategic management scholars with more of an economics background arguably being more disposed towards reductionism for disciplinary reasons than strategic management scholars with more of a sociology background.
} 
management research to increase the richness of the field - it is advisable to be explicit about what reductionism does and does not entail. It may be easiest to start with the latter.

Reductionism is occasionally taken to imply a denial of the phenomenon of “emergence.” Whatever that may be in a broader disciplinary context, such a denial is not characteristic of reductionism in social science, including strategic management. Reductionism is fully compatible with acknowledging that unintended consequences take place, for example. Furthermore, reductionism in social science is sometimes taken to mean that the analyst must always make reference to the full set of concrete actions, preferences, beliefs, etc. of concrete agents when trying to explain a phenomenon on the social domain. Obviously, this is usually not feasible, first, because of the sheer number of interacting agents and the complexity of their interaction - a problem that is occasionally referred to as “Cournot's Problem” (e.g., Davis, 2003)— , and, second, because of limited access to the preferences and beliefs of the relevant agents. Whatever that may be, ${ }^{7}$ no such extreme reductionism is advocated here.

\section{Reductionism, Black Boxes, and Structures}

Although reductionism seeks to eschew explanatory black boxes in principle, sometimes a case can be made for some degree of black box explanation. Apart from obvious disciplinary reasons, ${ }^{8}$ the reason for allowing some black boxes to enter explanation is explanatory parsimony. As Lewis (1986: 214) explains,

[a]ny particular event that we might wish to explain stands at the end of a long and complicated causal history. We might imagine a world where causal histories are short and simple; but in the world as we know it, the only question is whether they are infinite or merely enormous.

Luckily, it is simply not always necessary to seek and perform "rock-bottom explanation" for an explanation to be valid. For example, the strategic management scholar who is cognizant of economics knows that under competitive conditions, decision-makers in firms only have a very limited feasible behavioural repertoire. If they do not choose an

\footnotetext{
${ }^{7}$ As an objection to reductionism, the argument is a red herring: Cournot's problem does not rule out the possibility of explaining in terms of tractable models.

${ }^{8}$ For example, most economists want to treat tastes as black boxes, because not doing so would take them into entirely unfamiliar psychological territory
} 
element of this set, they will not survive. Thus, although there is no break with the ontological position that only individuals can choose, our strategic management scholar pragmatically recognizes that a structure (i.e., competitive conditions) can substitute in an explanatory sense for a much more complicated explanation involving individual action and interaction. ${ }^{9}$ However, being a proper reductionist, he knows that such a "structural" story is at best a reduced form explanation, that is, shorthand for something much more complicated. Economists and strategic management scholars perform somewhat related explanatory operations when they construct firm-level arguments. Thus, to involve the argument in an explanation that "a firm has a strategy" or "acts in a certain way" is, of course, shorthand for a complex set of underlying individual actions and interactions.

\section{Reductionism and Methodological Individualism}

In a social science context, reduction and reductionism is intimately associated with "methodological individualism." ${ }^{10}$ Reductionism in social science implies methodological individualism. Methodological individualism defines, as it were, the limits to reduction in social science, because it implies that social science explanation can stop at the level of individuals. There is no need to proceed further down the explanatory ladder. ${ }^{11}$

In its strongest form, methodological individualism asserts that in explanations of social phenomena reference is allowed only to individuals, their properties and their (inter)actions. Thus, at no point in the explanation can reference be made to supraindividual entities as in any way acting as causal agents. On this program, explaining, for example, "the strategy of a firm" must always involve making reference to the mental states of all relevant organizational stakeholders. ${ }^{12}$ Many (in fact, most) methodological

\footnotetext{
${ }^{9}$ For related arguments, see Koppl and Langlois (1991) and Satz and Ferejohn (1994). Koppl and Langlois argue that the argument originates with the economist Fritz Machlup.

${ }^{10}$ See Udehn (2001) for a recent overview, or O’Neill (1973) for a compilation of key readings.

11 Methodological individualists are often charged with the claim that their emphasis on the individual is arbitrary as one might as well take, for example, the "selfish gene" as the fundamental unit. However, this argument commits the "driver's seat fallacy", to wit, "[g]enes build bodies. ... Once the body is built, the genes have no control or influence on what those bodies do. It makes no more sense to say that genes drive our thoughts and emotions than it does to say that genes pump our blood. Our heart pumps our blood and our brain drives our thoughts and emotions ... Our genes are not in the driver's seat, we are” (Markoczy and Goldberg, 1998: 390).

12 Clearly, this program will often not be completely practicable for empirical reasons: It is usually impossible to obtain the necessary empirical information that is necessary to perform such a fine-grained explanation.
} 
individualists do not espouse this strong form. For example, Agassi (1960) argues that reference to institutions, clearly a collective concept, can be permitted in social science explanation, and many methodological individualists would argue that reference to collective concepts is permissible, and sometimes necessary as a sort of explanatory shorthand. In the context of strategic management, the collective concept of (firm-level) capabilities may be invoked as a handy explanatory shorthand. However, all methodological individualists insist that ultimately collective phenomena must be reduced to and explained in terms of individuals, that is, individual endowments, intentions, desires, expectations, and goals (cf. Hayek, 1955; Elster, 1989). Thus, the methodological individualist strategy scholar will be sceptical of the use of the notion of capabilities until the individual level foundations of this concept have been clarified. ${ }^{13}$

In contrast, methodological collectivism starts from the assumption that collectives are somehow independent from individuals and can therefore be taken as "primitives" in social science explanation. That is, collectives such as organizations, and "social facts" such as institutions, culture and capabilities serve as the primary independent variables determining individual and collective behaviour and outcomes (e.g., DiMaggio and Powell 1991: 8). The argument is that structure and institutions are prior to individuals in influencing (and even determining) choice sets and behaviour. In general, individual-level explanation is rejected in favour of collective explanation.

In terms of the earlier emphasis on opening up black boxes and uncovering causal mechanisms, it is clear that methodological individualists and methodological collectivists differ strongly with respect to which boxes need to be opened and which mechanisms deserve emphasis, and perhaps even which mechanisms exist. In other words, ontological positions are very likely to accompany methodological positions. Thus, a hardcore methodological individualist (if such exist) will deny any top-down causation and insist that all that matters is bottom-up causation (i.e., from individuals to collectives). A moderate methodological individualist may accept that at least metaphorically (cf. the earlier notion of explanatory shorthand) institutions exert influence on individual

\footnotetext{
${ }^{13}$ Will he accept that capabilities exist? As I see it, the methodological individualist strategic management scholar may admit ontological status to capabilities in the sense that acknowledging that capabilities describe patterns of specialization and co-specialization of firm members' knowledge and actions that are specific to a given firm. As Felin and Hesterly (2007) notes such an argument is espoused in, for example, the view that organizations are "strong situations" (Davis-Blake and Pfeffer 1989).
} 
behaviour, for example, in the sense that "they" structure incentives and therefore impact behaviour (Boudon, 1998). Hardcore collectivists (if such exist) may argue that causal relations that operate wholly on the collective level have real existence and are not just explanatory shorthand.

\section{THE EVOLUTION OF STRATEGIC MANAGEMENT: \\ OSCILLATING BETWEEN MICRO AND MACRO}

\section{The Swinging Strategic Management Pendulum}

In a magisterial paper Hoskisson et al. (1999) surveyed two decades of research in strategic management and likened the evolution of the field to a swinging pendulum. Whereas early work emphasized rich case description of individual firms and individual managers' behaviors, around 1980 there was a move away from this inside perspective towards more of an outside perspective, based on industrial economics and strongly emphasizing cross-sectional work and a general quest for generalization. Without dropping these ambitions, work on strategic groups, competitive dynamics, and boundary relationships between firms began to swing the pendulum back towards more of an internal focus as the 1980s progressed. The strong emphasis on transaction costs economics (Williamson, 1985) in the mid- to the end of the 1980s signified an intermediate position of the pendulum. The rise of the resource-based view towards the end of the 1980s swung the pendulum fully back towards an emphasis on the internal aspects of firms, and arguably a more eclectic approach to empirical research.

The swinging pendulum thesis is not a normative device; it is purely a device constructed for the purpose of historical reconstruction, and for demonstrating how changing theories imply different empirical research methods. To the extent that a view on progress in strategic management is present in the Hoskisson et al. (1999) piece, progress is a matter of being better able to cope with problems, old and new (e.g., globalization), integration of diverse perspectives, and more rigorous empirical techniques (see also Hitt et al., 1998). In fact, the issue of scientific progress is seldom addressed in the strategic management field, although some early papers highlighted it (Camerer, 1985; Balakrishnan et al., 1989). In contrast, the issue is directly confronted in the following, making use of a variation on the swinging pendulum thesis.

\section{Scientific Progress in the Strategic Management Field}


So, has the strategic management field made scientific progress? Obviously, how that question is answered depends on which criteria are applied and even on how these criteria are interpreted. On the basis of criteria essentially borrowed from economics and the growth of knowledge literature, Camerer (1985) concluded that strategic management research had not made any substantial theoretical progress. In developing prescriptions for research, he stressed conventionalist criteria such as the "coherence" of the theoretical structure, and in general put forward a strong advocacy for the position that “ ... deductive use of mathematics and economic concepts is the best way to answer (and ask) corporate strategy questions” (1985: 1). Mahoney (1993) argued that the alleged “coherence” may effectively translate into suppressing (necessary) diversity. On the basis of what seems to be an instrumentalist criterion Arend (2003: 283) argued that "If ...a science is defined by an ability to predict and control the dependent variables of interest then strategy research cannot ultimately fare well. Perhaps a new definition is needed to provide a fairer measure of progress in strategy research.” While Arend may pass unnecessarily harsh judgment, the argument here is that his call for new criteria for assessing scientific progress in the strategic management is well taken. One such new criterion is analytical reduction, as has just been suggested.

\section{Levels of Analysis}

As Hackman (2003: 905) notes, "[r]egardless of the level of analysis at which we begin, we like to move to the next level for our explanations.” For the practising social scientist that level, Hackman explains by means of examples, typically lies lower down, not up. ${ }^{14}$ However, it is not the case that the strategic management field has exhibited a natural tendency to adopt increasingly reductionist or micro-oriented explanations. On the contrary, the field has, taken as a whole demonstrated a preference for supra-individual levels of analysis, whether capabilities/competencies/core competencies/dynamic capabilities, firm, group, or industry levels. Of course, there is nothing surprising in this, given that the key dependent variables in strategic management research have typically been located at the firm level. However, to work at levels of analysis that are higher than that of the individual does not, of course, rule out the need for establishing micro-

\footnotetext{
${ }^{14}$ Hackman, however, comes out in favour of a strategy of temporarily "bracketing" the focal level of analysis and focusing attention on the level immediately below and immediately above this level to gain increased understanding
} 
foundations for such aggregate work (i.e., the analytical convenience or necessity of supra-individual levels of analysis does not make obviate micro-foundations). However, the efforts to build explicit micro-foundations have been very few. Therefore, there have also been very few attempts to seriously reconcile micro and macro-levels, ${ }^{15}$ in spite of much recent attention being paid to "levels issues," "multiple level analysis" and the like in management in general (e.g., Klein et al., 1994; Felin and Hesterly, 2007) .

There are various reasons why this sort of inquiry has so far been largely absent from strategic management. At the most basic level, strategic management is still a young field: No or few fields begin in a multi-level mode and in social science micro-foundations do not necessarily come first. ${ }^{16}$ Another reason is that in an inherently applied and practical discipline, implicit consensus may arise that issues of micro-foundations and of bridging levels are best left at the level of the base disciplines (e.g., psychology, economics, sociology inquiry. A third possible reason is that strategic management may be inherently pluralistic (Mahoney 1993; Mahoney and Pandian 1993) and this precludes building specific micro-foundations (Felin and Foss 2005). Whatever all that may be, strategic management has usually been characterized by collective level theorizing (see also Felin and Hesterly 2005), as will be discussed next.

\section{Strategic Management in the Aggregate Mode}

Hoskisson et al. (1998) note - correctly — that strategy thinking began with case studies of single firms and an emphasis on the general manager. However, as an analytical enterprise, strategic management rather began in a more aggregate mode. Early thinking (beginning of the 1970s) coming out of the Boston Consulting Group stressed firm-level learning curve advantages with no attention being paid to the underlying intraorganizational generative processes of individual action and interaction that are ultimately responsible for the learning-curve phenomenon. Research inspired by the Profit Impact of Market Strategy project begun in the mid-nineteen sixties at General Electric and expanded upon by the Management Institute at Harvard from the beginning of the 1970s

\footnotetext{
${ }^{15}$ Usually, the industry and the firm levels are "aligned" through application of the SWOT framework, the SW representing the firm level and the OT the industry level. For a forceful critique of the soundness of this, see Makadok (2005).

${ }^{16}$ Even economics began in the aggregate mode. Explicit microeconomics only really arrived with the marginalist revolution(s) of the 1870s, that is, about a hundred years after Adam Smith's classic (and two hundred years after William Petty).
} 
entailed a search for reduced form correlations between profit variables and various potential independent variables that defined an aggregative style of theorizing that is still very much present in the field. The focus of the PIMS project arguably also helped to pave the way for the field's perhaps first serious analytical breakthrough, namely Porter's (1980) industry analysis/positioning approach.

Transferring industrial organization economics to the strategy field, Porter's approach placed literally all of the explanatory burden on the aggregate characteristics of the environment, as captured in the famous " 5 forces." The firm as has so often been observed is completely blackboxed in this approach. Managers are mentioned, but only as the agents that have to carry out the analysis of industries and position the firm in the chosen industries. Their skills at doing this are presumably the main source of competitive advantage. Of course, as a practising economist Porter cannot be expected to have any particular sympathy for methodological collectivism. And his industry analysis does not harbour any ontological pretensions with respect to the existence of industries as anything other but producers that recognize that their products are close or relatively close substitutes. Indeed, as Porter (1980) himself stresses, the five forces approach used as a strategic tool is first and foremost a first cut at organizing information of relevance to the firm. While starting from this cut, more sophisticated strategic analysis must deal with strategic groups and mobility barriers, with pricing tactics, and the like.

In fact, later strategic management work that builds from industrial organization economics has typically dealt with exactly these kind of more fine-grained issues. As a result, some of the somewhat fuzzy collective categories that loom so large in Porter's early work disappear. Thus, instead of anonymous “forces” now come well-specified cooperative and non-cooperative games with (respectively) buyers/suppliers/complementors and competitors (Ghemawat, 1998; Brandenburger and Nalebuff, 1996) where the players are clearly identified, and — at least in the case of noncooperative games - their interaction is explicitly modelled. The case of the Porter approach nicely illustrates how an aggregative approach that places all of the informational burden on the analytical level immediately above the focal firm sacrifices informational content. Thus, the industry analysis/positioning has nothing in itself to say about firm-level competitive advantage. 


\section{Towards Micro - and Back to Collectives and Collectivism}

The RBV has very often been portrayed as an approach that supplied the missing pieces, specifically the analysis of (firm-level) competitive advantage, ${ }^{17}$ by taking an explicit focus on the resources that firms control. It is often informally seen as an instance of scientific progress because it treated a hitherto untheorized set of mechanisms, that is, the links from resources to competitive advantage and in turn to performance. The other side of that coin is that the RBV was reductionist in the sense that it literally dug deeper than rival perspectives by placing the primary explanatory burden on the resources controlled by a firm rather than on industry structure and competitive interaction. The individual resource would, at least on first inspection, seem to lie on a substantially lower level of analysis than the industry, the group or the firm. Thus, the RBV would seem to be well suited to exploring, for example, how individual employees contribute to value creation and how created value is distributed as a result of bargaining processes among the various stakeholders whose cooperation takes place under the legal shell represented by the firm (Wernerfelt, 1989). This potential for micro-analysis was, however, sidetracked for a long time, until the important recent work of Coff (1999) and Lippman and Rumelt (2003a\&b).

It is quite arguable that one of the reasons why the RBV gained so much success is exactly the feature of digging deeper. Not only may this has been recognized as an independent achievement (as the above suggests that indeed it should), but it also had the advantage of bringing the view in contact with organizational theory (in a broad sense, including organizational economics and organizational behaviour), human resource management, research on ICT and much other strategically relevant research that was hard to link to the more aggregative Porter approach.

However, as time unfolded, several things happened that implied that strategic management did not really fully release the potential for micro-analysis that the advent of the RBV signalled. First, standard definitions of a "resource" did not take an explicit micro-perspective. Thus, Barney (1991) defined a resource in a rather inclusive manner as "anything that may be thought of as an advantage to a firm." Clearly, this might conceivably encompass organization-level, collective resources, such as capabilities,

\footnotetext{
${ }^{17}$ Such a reading stresses (positive) complementarity between the Porter approach and the RBV. That this reading may be inconsistent is forcefully argued by Makadok (2005).
} 
culture and the like. Dierickx and Cool's (1989) extremely influential analysis was widely interpreted as implying that "stand-alone" resources acquired on strategic factor markets could not in general be expected to give rise to competitive advantage simply because they were traded. Whatever we may think of the soundness of this conclusion (and for the contrary view, see Barney, 1986 and more Denrell, Fang and Winter, 2003), the perceived force of its logic directed attention to "socially complex," “collectively held” resources, such as the "core competencies" or "capabilities" that were gaining currency in the beginning of the 1990 s. $^{18}$

There was a move back to the collective level, as strategy scholars increasingly converged on organizational capabilities as a key construct (Eisenhardt and Martin, 1999; Winter, 2003). Indeed, the organizational capabilities approach may now be the predominant way of thinking about heterogeneity in strategic management. Sustained competitive advantage, a firm-level phenomenon, is now directly explained in terms of capabilities, competencies, etc., that is, in terms of other firm-level phenomena. This is methodological collectivism (Felin and Foss, 2005; Felin and Hesterly, 2007).

\section{CONCLUDING DISCUSSION}

Although it has been claimed that the degree of reflexivity in strategic management is low (Pettigrew et al., 2002: 9, 11), methodological reflection has actually been part of the field almost since its inception (e.g., Bowman, 1974). A theory of science based chapter was part of the seminal Schendel and Hofer (1979) collection of essays (i.e., Spender, 1979). Methodology papers have continuously appeared in the Strategic Management Journal. In addition, strategic management scholars are (as is the case of most practicising scientists) active implicit theorists of science, making essentially methodological comments and observations on existing work in the field. In terms of the trends of methodological discourse in strategic management, early work was clearly under the influence of the growth of knowledge literature (particularly Balakrishnan et al., 1989), but current methodological work makes a rather pluralistic impression, ranging from constructivism to the application of formal logic.

\footnotetext{
${ }^{18}$ At the AoM meetings in 2004 at which Felin and Foss (2005) was presented, several members of the audience argued that the emphasis in that paper on micro-foundations were not relevant to strategic analysis, because all sustainable heterogeneity was located at the collective level.
} 
Whereas the normative aspect of the methodological enterprise has been somewhat toned down in recent writings this chapter has introduced a perspective that 1 ) is commonsense, 2) is novel, and 3) may capture important aspects of the practice of strategic management research. Thus, the argument has been that reduction may instantiate scientific progress, and that important parts of the evolution of the strategic management field can be understood as a quest for identifying the deep structure of competitive advantage. Although the pendulum has shifted back and forth between macro and micro perspectives, currently staying on the macro side (i.e., the capabilities perspective) there are signs that more micro perspectives are making themselves felt. Thus, increasingly strategy scholars emphasize that value creation may have an important individual level component (Felin and Hesterly, 2007) and that individuals appropriate (Coff, 1997, 1999) through complex interaction (Lippman and Rumelt, 2003a). The recent strong emphasis on entrepreneurship in the field seems to indicate a similar move towards foundations rooted in the actions and interaction of individuals. In terms of the methodological perspective developed in this paper, this tendency is a distinct example of progress. 


\section{REFERENCES}

Abell, Peter. 2001. "Causality and Low-Frequency Complex Events,” Sociological Methods and Research 30: 57-80.

Abell, Peter. 2004. "Narrative Explanation: An Alternative to Variable-Centered Explanation,” Annual Review of Sociology 30: 287-310.

Agassi, Joseph. 1960. “Methodological Individualism”, British Journal of Sociology 11: 244-70.

Alvesson, Mats and Hugh Wilmott. 1995. "Strategic Management and Domination and Emancipation: From Planning and Process to Communication and Praxis,” Paul Shrivastava and C. Stubbart, eds. 1995. Advances in Strategic Management: Challenges from Outside the Mainstream. Greenwich, Conn.: JAI Press, pp. 85-112.

Arend, Richard J. 2003. "Revisiting the logical and research considerations of competitive advantage”, Strategic Management Journal 24: 279-284.

Arrow, Kenneth J. 1951. Social choice and individual values. New York: Wiley \& Sons.

Backhouse, Roger A., ed. 1994. New Directions in Economic Methodology, London: Routledge.

Balakrishnan, Srinivasan, Cynthia A Montgomery, and Birger Wernerfelt. 1989. "Strategy Content and the Research Process: A Critique and Commentary," Strategic Management Journal 10: 189-197.

Barney, Jay B. 1986. ”Strategic Factor Markets”, Management Science 32: 1231-1241.

Barney, Jay B. 1991. "Firm Resources and Sustained Competitive Advantage”, Journal of Management 17: 99-120.

Barney, Jay B. 2001. "Is the Resource-based 'View' a Useful Perspective for Strategic Management Research? Yes,” Academy of Management Review 26: 41-57.

Bhaskar, Roy. 1978. A Realist Theory of Science. 2nd ed., Brighton: Harvester.

Black, J. and Kimberly Boal. 1994. "Strategic Resources: Traits, Configurations, and Paths to Sustainable Competitive Advantage,” Strategic Management Journal (Summer Special Issue) 15: 131-148.

Blaug, Mark. 1980. The Methodology of Economics, Cambridge: Cambridge University Press.

Bloor, David. 1976. Knowledge and Social Imagery. London. Routledge.

Bogner, William C., Joseph T. Mahoney and Howard Thomas. 1998. "Paradigm Shift: The Parallel Origin, Evolution and Function of Strategic Group Analysis With the Resource-based View," Advances in Strategic Management 15: 63-102.

Boudon, Raymond. 1998. "Social Mechanisms without Black Boxes,” in Peter Hedström and Richard Swedberg, eds., Social Mechanisms: An Analytical Approach to Social Theory. Cambridge: Cambridge University Press.

Bourgeois, L.J. 1984. "Strategic Management and Determinism," Academy of Management Review 9: 586-596. 
Bowman, Edward. H. 1974. "Epistemology, Corporate Strategy and Academia," Sloan Management Review 15: 35-50.

Bowman, Edward H., Harbir Singh, and Howard Thomas. 2002. "The Domain of Strategic Management: History and Evolution,” in Howard Thomas and Andrew Pettigrew, eds. Handbook of Strategy and Management. London: Sage.

Bowman, Edward H. 1990. "Strategy Changes: Possible Worlds and Actual Minds," in J.F. Frederickson, ed. Perspectives on Strategic Management, New York: Harper.

Boyd, Brian K., Sydney Finkelstein, and Steve Gove. 2005. "How Advanced is the Strategy Paradigm? The Role of Particularism and Universalism in Shaping Research Outcomes,” Strategic Management Journal 26: 841-854.

Brandenburger, Adam and Barry Nalebuff. 1996. Co-Opetition. Currency-Doubleday.

Brønn, C. 1998. "Applying Epistemic Logic and Evidential Theory to Strategic Arguments,” Strategic Management Journal 19: 81-95.

Camerer, Colin. 1985. "Redirecting Research in Business Policy and Strategy,” Strategic Management Journal 6: 1-15.

Coff, Russell. 1997. "Human Assets and Management Dilemmas: Coping With Hazards on the Road to Resource-based Theory," Academy of Management Review 22: 374402.

Coff, Russell. 1999. "When Competitive Advantage Doesn't Lead to Performance: Resource-based Theory and Stakeholder Bargaining Power," Organization Science 10: 119- 133.

Coleman, James S. 1990. Foundations of Social Theory. Cambridge (Mass.)/London: The Belknap Press of Harvard University Press.

Davis, John B. 2003. The Theory of the Individual in Economics: Identity and Value. London: Taylor and Francis.

Davis-Blake, Allison and Jeffrey Pfeffer. 1989. "Just a Mirage: The Search for Dispositional Effects in Organizational Research," Academy of Management Review, 14: 385-400.

Denrell, Jerker, Christina Fang, and Sidney G. Winter. 2003. "The Economic of Strategic Opportunity.” Strategic Management Journal 24: 977-990.

Dierickx, Ingemar and Karel Cool. 1989. "Asset Stock Accumulation and the Sustainability of Competitive Advantage,” Management Science 35: 1504-1511.

Dosi, Giovanni. 1995. "Hierarchies, Markets and Power: Some Foundational Issues on the Nature of Contemporary Economic Organizations”, Industrial and Corporate Change 4: 1-19.

Dupré, John. 2001. “Economics without Mechanism,” in Uskali Mäki, ed. 2001. The Economic World View. Cambridge: Cambridge University Press.

Dupree, J. 1993. The Disorder of Things. Harvard University Press.

Durand, Rodolphe. 2002. "Competitive Advantages Exist: A Critique of Powell," Strategic Management Journal 23: 867-872. 
Elster, Jon. 1989. Nuts and Bolts for the Social Sciences. Cambridge: Cambridge University Press.

Farjoun, Moshe. 2002. "Towards an Organic Perspective on Strategy" Strategic Management Journal 23: 561 -594

Felin, Teppo and Nicolai Foss. 2005. "Strategic Organization: a Field in Search of Microfoundations," forthcoming in Strategic Organization.

Felin, Teppo and W.S. Hesterly. 2007. “The Knowledge-Based View, Heterogeneity, and the Individual: Philosophical Considerations on the Locus of Knowledge," forthcoming in Academy of Management Review.

Ferejohn, John and Debra Satz. 1994. "Rational Choice and Social Theory", Journal of Philosophy, 91: 71-87.

Foss, Kirsten and Nicolai J. Foss. 2005. "Value and Transaction Costs: How Property Rights Economics Furthers the Resource-based View," Strategic Management Journal, 26: 541-553.

Foss, Nicolai J. 1998. "The New Growth Theory: Some Intellectual Growth Accounting,” Journal of Economic Methodology.

Foss, Nicolai. 2000. "Equilibrium and Evolution: The Conflicting Legacies of Demsetz and Penrose," in Nicolai J Foss and Paul L. Robertson, eds. Resources, Technology, and Strategy. London: Routledge.

Friedman, Milton. 1953. "The Methodology of Positive Economics," in idem. 1953. Essays in Positive Economics, Chicago: University of Chicago Press.

Ghemawat, Pankaj. Games Business Play. Cambridge: MIT Press.

Godfrey, Paul C. and Charles W. L. Hill. 1995. "The Problem of Unobservables in Strategic Management Research,” Strategic Management Journal 16: 519-533.

Hackman, J. Richard. 2003. "Learning More by Crossing Levels: Evidence from Airplanes, Hospitals and Orchestras,” Journal of Organizational Behavior 24: 905922.

Hands, D. Wade. 1991. "The Problem of Excess Content: Economics, Novelty, and a Long Popperian Tale,” in Neil de Marchi and Mark Blaug, eds. Appraising Economic Theories: Studies in the Methodology of Research Programs, Aldershot: Edward Elgar.

Harré, Rom. 1970. The Principles of Scientific Thinking. London: Macmillan.

Hayek, Friedrich A. von. 1955. The Counter Revolution of Science. Chicago: University of Chicago Press.

Hedström, Peter and Richard Swedberg, eds. 1998. Social Mechanisms: An Analytical Approach to Social Theory. Cambridge: Cambridge University Press.

Hitt, Michael A., Javier Gimeno, and Robert E. Hoskisson. 1998. "Current and Future Research Methods in Strategic Management," Organizational Research Methods 1: 6-44. 
Hoskisson, Robert E., Michael A. Hitt, William P. Wan and Daphne Yiu. 1999. „Theory and Research in Strategic Management: Swings of a Pendulum,“ Journal of Management 25: 417-456.

Jones, Richard. 2000. Reductionism: Analysis and the Fullness of Reality. Bucknell University Press.

Kincaid, Harold. 1997. Individualism and the Unity of Science: Essays on Reduction, Explanation and the Special Sciences. Oxford: Rowman and Littlefield Publishers, Inc.

Klein, Katherine J., Fred Dansereau, and Rosalie J. Hall. 1994. „Levels Issues in Theory Development, Data Collection, and Analysis,” Academy of Management Review 19: 195-229.

Knights, David and Gareth Morgan. 1991. "Strategic Discourse and Subjectivity: Towards a Critical Analysis of Corporate Strategy in Organizations," Organization Studies 12: 251-273.

Koppl, Roger and Richard N. Langlois. 1991. "Fritz Machlup and Marginalism: A Reevaluation,” Methodus 3: 86-102.

Kuhn, Thomas. 1970. The Structure of Scientific Revolutions. Chicago: University of Chicago Press.

Kwan K-M and Eric Tsang. 2001. "Realism and constructivism in strategy research: a critical realist response to Mir and Watson”, Strategic Management Journal, 22: 1163-1168

Lakatos, Imre. 1970 "Falsification and the methodology of scientific research programmes," in Imre Lakatos and Alan Musgrave, (eds.) Criticism and the Growth of Knowledge. Cambridge: Cambridge University Press, 91-196.

Laudan, Larry. 1977. Progress and its Problems: Toward a Theory of Scientific Growth. London: Routledge.

Lazarsfeld, P.F. and P. Menzel. 1960. "On the relation between individual and collective properties” In A. Etzioni, ed., Complex organizations: a sociological reader. New York: Holt, Rinehart and Winston.

Lewis, David. 1986. Philosophical Papers. Oxford: Oxford University Press.

Lippman, Steven A. and Richard P. Rumelt. 1982. "Uncertain Imitability: An Analysis of Interfirm Differences Under Competition,” Bell Journal of Economics 13: 418-438.

Lippman, Steven A. and Richard P. Rumelt. 2003a. "A Bargaining Perspective on Resource Advantage,” Strategic Management Journal 24: 1069-1086.

Lippman, Steven A. and Richard P. Rumelt. 2003b. "The Payments Perspective," Strategic Management Journal 24: 903-927.

Lipsey, Richard. 1966. An Introduction to Positive Economics. London: Weidenfeld and Nicholson.

Lipton, Peter. 2004. Inference to the Best Explanation. London: Routledge.

MacCloskey, Donald. 1983. "The Rhetorics of Economics," Journal of Economic Literature 21: 481-517. 
Mahoney, Joseph T. and J. Rajendran Pandian. 1992. "The Resource-Based View within the Conversation of Strategic Management”, Strategic Management Journal 13: 363-380.

Mahoney, Joseph T. 1993. "Strategic Management and Determinism: Sustaining the Conversation,” Journal of Management Studies 30: 173-191.

Makadok, Richard and Jay B. Barney. 2001. "Strategic Factor Market Intelligence: an Application of Information Economics to Strategy Formulation and Competitor Intelligence,” Management Science 47: 1621-1638.

Makadok, Richard. 2005. "The Competence-Collusion Puzzle and the Four Theories of Profit: Why Good Resources Go to Bad Industries,” Working Paper.

Mäki, Uskali. 1992. "On the Method of Isolation in Economics," Poznan Studies in the Philosophy of the Sciences and the Humanities 38: 147-168.

Mäki, Uskali. 2001. "The Way the World Works (www): Towards an Ontology of Theory Choice,” idem. 2001. The Economic World View. Cambridge: Cambridge University Press.

Marchi, Neil de and Mark Blaug, eds. 1991. Appraising Economic Theories: Studies in the Methodology of Research Programs, Aldershot: Edward Elgar.

Markóczy, Lívia and Jeff Goldberg. 1998, "Management, Organization, and Human Nature: an Introduction," Managerial and Decision Economics 19: 387-409. Mintzberg, Henry, Joseph Lampel, and Bruce Ahlstrand. 1998. Strategy Safari. New York: Free Press.

Menger, Carl. 1883. Investigations into the Method of the Social Sciences with Special Reference to Economics, Leipzig. English translation (1985) Louis Schneider (ed.), New York: New York University Press

Milgrom, Paul J. and John D. Roberts. 1992. Economics, Organization, and Management. New York: Prentice Hall.

Mir, Raza and Andrew Watson. 2000. "Strategic management and the philosophy of science: the case for a constructivist methodology", Strategic Management Journal 21: 941 - 953.

Mir, Raza and Andrew Watson. 2001. "Critical realism and constructivism in strategy research: toward a synthesis”, Strategic Management Journal 22: 1169 - 1173.

Oliver, Christine. 1997. "Sustainable Competitive Advantage: Combining Institutional and Resource-based Views,” Strategic Management Journal 18: 697-713.

O’Neill, John, ed. 1973. Modes of Individualism and Collectivism. London: Heinemann.

Peteraf, Margaret A. 1993. "The Cornerstones of Competitive Advantage: A ResourceBased View”, Strategic Management Journal 14: 179-191.

Popper, Karl R. 1934. The Logic of Scientific Discovery. Vienna: Springer.

Popper, Karl R. 1957. The Poverty of Historicism. (Reprint 1999). London: Routledge.

Porter, Michael E. 1980. Competitive Strategy. New York: Free Press.

Porter, Michael E. 1991. "Towards a Dynamic Theory of Strategy," Strategic Management Journal (Summer Special Issue) 12: 95-117. 
Powell, Thomas. 2001. "Competitive Advantage: Logical and philosophical considerations” Strategic Management Journal 22: 875-888.

Powell, Thomas. 2003. "Strategy without ontology”, Strategic Management Journal 24: $285-291$

Priem, Richard L. and Butler, J. E. 2001. "Tautology in the Resource-Based View and the Implications of Externally Determined Value: Further Comments," Academy of Management Review 26: 57-65.

Salmon, Wesley. 1997. Causality and Explanation. Oxford: Oxford University Press.

Schendel, Dan and Charles Hofer, eds. 1979. Strategic Management: A New View of Business Policy and Planning. Boston MA: Little, Brown.

Smircich, L. and C. Stubbard. 1985. "Strategic Management in an Enacted World," Academy of Management Review 10: 724-736.

Silberstein, Michael. 2002. "Reduction, Emergence and Explanation," in Peter Machamer and Michael Silberstein, eds. The Blackwell Guide to the Philosophy of Science. Oxford: Blackwell Publishers.

Spender, J.C. 1979. “Theory Building and Theory Testing in Strategic Management,” in D. Schendel and C. Hofer, eds. Strategic Management: A New View of Business Policy and Planning. Boston MA: Little, Brown.

Tsoukas, Haridimos and Christian Knudsen. 2002. "The Conduct of Strategy Research,” in Howard Thomas and Andrew Pettigrew, eds. Handbook of Strategy and Management. London: Sage.

Udehn, Lars. 2001. Methodological individualism: Background, history and meaning. London, New York: Routledge.

Wernerfelt, Birger. 1984. “A Resource-based View of the Firm,” Strategic Management Journal 5: 171-180.

Wernerfelt, Birger. 1989. "From Critical Resources to Corporate Strategy," Journal of General Management.

Whipp, R. 1996. “Creative Deconstruction: Strategy and Organization,” in S.R. Clegg, C. Hardy, and W.R. Nord, eds. Handbook of Organization Studies. London: Sage.

Williamson, Oliver E. 1985. The Economic Institutions of Capitalism. New York: Free Press.

Williamson, Oliver E. 1996. "Economic Organization: The Case for Candor,” Academy of Management Review, 21: 48-57.

Winter, Sidney G. 2003.”Understanding Dynamic Capabilities,” Strategic Management Journal 24: 991-995. 


\section{SMG - Working Papers \\ www.cbs.dk/smg \\ 2003}

2003-1: Nicolai J. Foss, Kenneth Husted, Snejina Michailova, and Torben Pedersen: Governing Knowledge Processes: Theoretical Foundations and Research Opportunities.

2003-2: Yves Doz, Nicolai J. Foss, Stefanie Lenway, Marjorie Lyles, Silvia Massini, Thomas P. Murtha and Torben Pedersen: Future Frontiers in International Management Research: Innovation, Knowledge Creation, and Change in Multinational Companies.

2003-3: Snejina Michailova and Kate Hutchings: The Impact of In-Groups and OutGroups on Knowledge Sharing in Russia and China CKG Working Paper.

2003-4: Nicolai J. Foss and Torben Pedersen : The MNC as a Knowledge Structure: The Roles of Knowledge Sources and Organizational Instruments in MNC Knowledge Management CKG Working Paper.

2003-5: Kirsten Foss, Nicolai J. Foss and Xosé H. Vázquez-Vicente: “Tying the Manager's Hands": How Firms Can Make Credible Commitments That Make Opportunistic Managerial Intervention Less Likely CKG Working Paper.

2003-6: Marjorie Lyles, Torben Pedersen and Bent Petersen: Knowledge Gaps: The Case of Knowledge about Foreign Entry.

2003-7: Kirsten Foss and Nicolai J. Foss: The Limits to Designed Orders: Authority under "Distributed Knowledge" CKG Working Paper.

2003-8: Jens Gammelgaard and Torben Pedersen: Internal versus External Knowledge Sourcing of Subsidiaries - An Organizational Trade-Off.

2003-9: Kate Hutchings and Snejina Michailova: Facilitating Knowledge Sharing in Russian and Chinese Subsidiaries: The Importance of Groups and Personal Networks Accepted for publication in Journal of Knowledge Management.

2003-10: Volker Mahnke, Torben Pedersen and Markus Verzin: The Impact of Knowledge Management on MNC Subsidiary Performance: the Role of Absorptive Capacity CKG Working Paper.

2003-11: Tomas Hellström and Kenneth Husted: Mapping Knowledge and Intellectual Capital in Academic Environments: A Focus Group Study Accepted for publication in Journal of Intellectual Capital CKG Working Paper.

2003-12: Nicolai J Foss: Cognition and Motivation in the Theory of the Firm: Interaction or "Never the Twain Shall Meet"? Accepted for publication in Journal des Economistes et des Etudes Humaines CKG Working Paper.

2003-13: Dana Minbaeva and Snejina Michailova: Knowledge Transfer and Expatriation Practices in MNCs: The Role of Disseminative Capacity.

2003-14: Christian Vintergaard and Kenneth Husted: Enhancing Selective Capacity Through Venture Bases. 


\section{4}

2004-1: Nicolai J. Foss: Knowledge and Organization in the Theory of the Multinational Corporation: Some Foundational Issues

2004-2: Dana B. Minbaeva: HRM Practices and MNC Knowledge Transfer

2004-3: Bo Bernhard Nielsen and Snejina Michailova: Toward a Phase-Model of Global Knowledge Management Systems in Multinational Corporations

2004-4: Kirsten Foss \& Nicolai J Foss: The Next Step in the Evolution of the RBV: Integration with Transaction Cost Economics

2004-5: Teppo Felin \& Nicolai J. Foss: Methodological Individualism and the Organizational Capabilities Approach

2004-6: Jens Gammelgaard, Kenneth Husted, Snejina Michailova: Knowledge-sharing Behavior and Post-acquisition Integration Failure

2004-7: Jens Gammelgaard: Multinational Exploration of Acquired R\&D Activities

2004-8: Christoph Dörrenbächer \& Jens Gammelgaard: Subsidiary Upgrading? Strategic Inertia in the Development of German-owned Subsidiaries in Hungary

2004-9: Kirsten Foss \& Nicolai J. Foss: Resources and Transaction Costs: How the Economics of Property Rights Furthers the Resource-based View

2004-10: Jens Gammelgaard \& Thomas Ritter: The Knowledge Retrieval Matrix: Codification and Personification as Separate Strategies

2004-11: Nicolai J. Foss \& Peter G. Klein: Entrepreneurship and the Economic Theory of the Firm: Any Gains from Trade?

2004-12: Akshey Gupta \& Snejina Michailova: Knowledge Sharing in Knowledge-Intensive Firms: Opportunities and Limitations of Knowledge Codification

2004-13: Snejina Michailova \& Kate Hutchings: Knowledge Sharing and National Culture: A Comparison Between China and Russia

\section{5}

2005-1: Keld Laursen \& Ammon Salter: My Precious - The Role of Appropriability Strategies in Shaping Innovative Performance

2005-2: Nicolai J. Foss \& Peter G. Klein: The Theory of the Firm and Its Critics: A Stocktaking and Assessment

2005-3: Lars Bo Jeppesen \& Lars Frederiksen: Why Firm-Established User Communities Work for Innovation: The Personal Attributes of Innovative Users in the Case of Computer-Controlled Music

2005-4: Dana B. Minbaeva: Negative Impact of HRM Complementarity on Knowledge Transfer in MNCs

2005-5: Kirsten Foss, Nicolai J. Foss, Peter G. Klein \& Sandra K. Klein: Austrian Capital 
Theory and the Link Between Entrepreneurship and the Theory of the Firm

2005-1: Nicolai J. Foss: The Knowledge Governance Approach

2005-2: Torben J. Andersen: Capital Structure, Environmental Dynamism, Innovation Strategy, and Strategic Risk Management

2005-3: Torben J. Andersen: A Strategic Risk Management Framework for Multinational Enterprise

2005-4: Peter Holdt Christensen: Facilitating Knowledge Sharing: A Conceptual Framework

2005-5 Kirsten Foss \& Nicolai J. Foss: Hands Off! How Organizational Design Can Make Delegation Credible

2005-6 Marjorie A. Lyles, Torben Pedersen \& Bent Petersen: Closing the Knowledge Gap in Foreign Markets - A Learning Perspective

2005-7 Christian Geisler Asmussen, Torben Pedersen \& Bent Petersen: How do we Capture "Global Specialization" when Measuring Firms' Degree of internationalization?

2005-8 Kirsten Foss \& Nicolai J. Foss: Simon on Problem-Solving: Implications for New Organizational Forms

2005-9 Birgitte Grøgaard, Carmine Gioia \& Gabriel R.G. Benito: An Empirical Investigation of the Role of Industry Factors in the Internationalization Patterns of Firms

2005-10 Torben J. Andersen: The Performance and Risk Management Implications of Multinationality: An Industry Perspective

2005-11 Nicolai J. Foss: The Scientific Progress in Strategic Management: The case of the Resource-based view

2005-12 Koen H. Heimeriks: Alliance Capability as a Mediator Between Experience and Alliance Performance: An Empirical Investigation Into the Alliance Capability Development Process

2005-13 Koen H. Heimeriks, Geert Duysters \& Wim Vanhaverbeke: Developing Alliance Capabilities: An Empirical Study

2005-14 JC Spender: Management, Rational or Creative? A Knowledge-Based Discussion

\section{6}

2006-1: Nicolai J. Foss \& Peter G. Klein: The Emergence of the Modern Theory of the Firm

2006-2: Teppo Felin \& Nicolai J. Foss: Individuals and Organizations: Thoughts on a Micro-Foundations Project for Strategic Management and Organizational Analysis

2006-3: Volker Mahnke, Torben Pedersen \& Markus Venzin: Does Knowledge Sharing 
Pay? An MNC Subsidiary Perspective on Knowledge Outflows

2006-4: Torben Pedersen: Determining Factors of Subsidiary Development

2006-5 Ibuki Ishikawa: The Source of Competitive Advantage and Entrepreneurial Judgment in the RBV: Insights from the Austrian School Perspective

2006-6 Nicolai J. Foss \& Ibuki Ishikawa: Towards a Dynamic Resource-Based View: Insights from Austrian Capital and Entrepreneurship Theory

2006-7 Kirsten Foss \& Nicolai J. Foss: Entrepreneurship, Transaction Costs, and Resource Attributes

2006-8 Kirsten Foss, Nicolai J. Foss \& Peter G. Klein: Original and Derived Judgement: An Entrepreneurial Theory of Economic Organization

2006-9 Mia Reinholt: No More Polarization, Please! Towards a More Nuanced Perspective on Motivation in Organizations

2006-10 Angelika Lindstrand, Sara Melen \& Emilia Rovira: Turning social capital into business? A study of Swedish biotech firms' international expansion

2006-11 Christian Geisler Asmussen, Torben Pedersen \& Charles Dhanaraj: Evolution of Subsidiary Competences: Extending the Diamond Network Model

2006-12 John Holt, William R. Purcell, Sidney J. Gray \& Torben Pedersen: Decision Factors Influencing MNEs Regional Headquarters Location Selection Strategies

2006-13 Peter Maskell, Torben Pedersen, Bent Petersen \& Jens Dick-Nielsen: Learning Paths to Offshore Outsourcing - From Cost Reduction to Knowledge Seeking

2006-14 Christian Geisler Asmussen: Local, Regional or Global? Quantifying MNC Geographic Scope

2006-15 Christian Bjørnskov \& Nicolai J. Foss: Economic Freedom and Entrepreneurial Activity: Some Cross-Country Evidence

2006-16 Nicolai J. Foss \& Giampaolo Garzarelli: Institutions as Knowledge Capital: Ludwig M. Lachmann's Interpretative Institutionalism

2006-17 Koen H. Heimriks \& Jeffrey J. Reuer: How to Build Alliance Capabilities

2006-18 Nicolai J. Foss, Peter G. Klein, Yasemin Y. Kor \& Joseph T. Mahoney: Entrepreneurship, Subjectivism, and the Resource - Based View: Towards a New Synthesis

2006-19 Steven Globerman \& Bo B. Nielsen: Equity Versus Non-Equity International Strategic Alliances: The Role of Host Country Governance

\section{7}

2007-1 Peter Abell, Teppo Felin \& Nicolai J. Foss: Building Micro-Foundations for the Routines, Capabilities, and Performance Links 
2007-2 Michael W. Hansen, Torben Pedersen \& Bent Petersen: MNC Strategies and Linkage Effects in Developing Countries

2007-3 Niron Hashai, Christian G. Asmussen, Gabriel R.G. Benito \& Bent Petersen: Predicting the Diversity of Foreign Entry Modes

2007-4 Peter D. Ørberg Jensen \& Torben Pedersen: Whether and What to Offshore?

2007-5 Ram Mudambi \& Torben Pedersen: Agency Theory and Resource Dependency Theory: Complementary Explanations for Subsidiary Power in Multinational Corporations

2007-6 Nicolai J. Foss: Strategic Belief Management

2007-7 Nicolai J. Foss: Theory of Science Perspectives on Strategic Management Research: Debates and a Novel View 